\title{
Smoking Methods and Microbiological Characteristics of Smoked Fishes: A Review
}

\section{Legese Hagos}

Ethiopian Institute of Agricultural Research, National Fishery and Aquatic Life Research Center, Sebeta, Ethiopia

Email address:

legesehagos2006@yahoo.com

\section{To cite this article:}

Legese Hagos. Smoking Methods and Microbiological Characteristics of Smoked Fishes: A Review. Journal of Food and Nutrition Sciences. Vol. 9, No. 5, 2021, pp. 113-116. doi: 10.11648/j.jfns.20210905.11

Received: September 2, 2021; Accepted: September 17, 2021; Published: September 26, 2021

\begin{abstract}
Fish is vertebrate animal with great importance for human nutrition. Fish contains a low-fat, a great source of protein, vitamins and minerals so that millions of people getting benefit from fish harvesting, processing, distributing and consuming. This review was initiated with the objective of assessing some smoking methods and the quality of microbiology on smoked fish. Fish is highly perishable and lose its freshness with in very short period of time unless different preservative methods are applied. To preserve and keep its quality and safety, smoking fish is one of the methods that keep quality and safety of the fish and fish products. Hot smoking, warm smoking and cold smoking are being applied nowadays. These smoking methods do have their own positive and negative impacts. Smoked fish products are rich in essential amino acids, fatsoluble vitamins, and unsaturated fatty acids that are considered healthy ready-to-eat products and it also have great importance to the consumer due to their desirable in taste, aroma, and color. Moreover, Smoking minimizes spoilage and pathogenic bacterial activities due to integrated effect of heating, drying, salting and also as a result of deposition of polyphenolic constituents on fish. To ensure the quality and safety as well as extend shelf life of fish and its product, smoking and proper handling of the food products is important. In addition to this, improving smoking techniques and materials that can give maximum nutritive quality and keep the optimum safety of the fish is highly recommended.
\end{abstract}

Keywords: Bacteria, Fish, Preservation, Smoking

\section{Introduction}

Fish is vertebrate animal that lives in the fresh and sea water [14]. According to the estimation Food and Agriculture Organization, increase in fish production from aquaculture will increase with annual growth rate of $4 \%$ and reach 109 million by 2030 [21]. Fish do have a great importance in human nutrition. Fish contains a low-fat, a great source of protein, vitamins and minerals [20]. Millions of people getting profit from Fish harvesting, handling, processing and distributing [2]. Animal based protein is the most important food protein found from animal sources. Globally, about 14\% of all animal protein available represented in the tropic [1]. Fish and fishery products are very essential food component for a large part of the world's population, with an average consumption level of $20.1 \mathrm{~kg}$ per capital [15]. Fish is relatively less costly and easily accessible source of protein in developing country. Fish is perishable and lose freshness in short time due to the microbial spoilage and autolytic [13].
Conservation of fresh fish in tropical region remains a problem because of lack of adequate infrastructure and the environmental condition that contribute for spoilage of fish in short time [7]. Various preservation methods are applied to prevent postharvest losses and spoilage. Some of them are frying, fermentation, drying, salting, and smoking [4]. Smoking implies fish to direct or indirect action of smoke during the incomplete combustion of certain trees used as fuel. Smoking of foodstuffs do have great importance on the improvement of food organoleptic characteristics, induces water loss, and reduces the microbial load [12]. Smoked fish products are rich in essential amino acids, minerals, fatsoluble vitamins, and unsaturated fatty acids that are considered healthy ready-to-eat products. Improving the shelf life of hot smoked rainbow trout will have economic value on the market demand that minimizes the loss [16]. Globally, fish are known for having nutritious food items. The need for fish consumption is growing due to having high protein with omega-3 and-6 polyunsaturated fatty acids, that are essential 
for human [24]. For having such numerous benefits of consuming fish and its products, fish processors have been searching for different methods that can easily be processed and keep its nutrition, safety and delicacy of taste that can be secured [18]. From these different techniques, drying, freezing, cooking, salting and smoking are known. Smoking is a traditional fish preservation method, having great importance worldwide [11]. Currently, smoking fish products have great importance to the consumer due to their desirable in taste, aroma, and color [8]. Smoking treatment preserves food by the synergetic effect of temperature, table salt, and other chemical substances released from sawdust with a reduced water activity [10]. Food items can be prevented from the growth of microbes and extend change of oxidation by smoking [17]. Smoking technology maintains good physicochemical characteristics of foods, such as $\mathrm{pH}$ level, volatile basic nitrogen level, thiobarbituric acid reactive substances level, textural characteristics, and fatty acid profile and eventually improves sensory quality to the endpoint consumer with extended shelf life [19].

\section{Fish Smoking Methods}

\subsection{Hot Smoking}

Hot smoking does have different main processes that: cooking; when the smoking is performed at temperatures above $80^{\circ} \mathrm{C}$, the flesh of the fish is cooked, the heat can destroy the microbes that found inside and, on the fish, and inactivate enzymes in the gut and flesh, drying: the smoke that produced from fire also generates heat that he to dry the fish and smoking; the smoke is produced by burning wood containing a number of compounds, some of which kill bacteria; the process has a preservative value. The smoking process can take the form of wet hot smoking or dry hot smoking. Both processes are carried out at temperatures high enough to cook the fish. Wet hot smoking usually takes about $1-2 \mathrm{~h}$ and yields a moist, versatile product with about 40 $55 \%$ moisture content but a limited shelf life of 1-3 days. Dry hot smoking, which is usually preceded by the former process, takes about 10-18 h, sometimes days, and yields fish with $10-15 \%$ moisture content, sometimes even below $10 \%$. Fish smoked by this process have a shelf life of 6-9 months when stored properly. The fish treated with hot smoking is ready to consume and has desired aroma. It is applied at the temperature of $50-80^{\circ} \mathrm{C}$ for $20-60 \mathrm{~min}$. [8].

\subsection{Warm Smoking}

It is fish smoking that carried out by applying a temperature between $25-50^{\circ} \mathrm{C}$.

\subsection{Cold Smoking}

Cold smoking treatment is that the flesh is not going to be cooked, the protein will not be coagulated, does no inactive spoilage enzymes or destroy the food pathogen so that storing the food inside the refrigerator until consumption is necessary [5]. Cold smoking is performed below $25^{\circ} \mathrm{C}$ and the temperature used in the cold smoking process varies depending on the species of fish but is usually between $15-23^{\circ} \mathrm{C}$.

\section{Microbiology of Smoked Fish}

Spoilage and pathogenic bactericidal activity of smoke are due to integrated effect of heating, drying, salting and also as a result of deposition of polyphenolic constituents on fish. polyphenolic constituents like formaldehyde and acetic acid are found to show bactericidal effect which can prevent fungal growth and can inhibit viral activities [3]. According to [22], the count of bacteria from smoked fish in improved smoking kiln; Total Plate Count, Salmonella, Total coliforms, and Escherichia coli count were $\left(1.936 \times 10^{6}, 1.550 \times 10^{4}\right.$, $2.00 \times 10^{4}$ and $0 \mathrm{cfu} / \mathrm{g}$ ) than fish smoked in traditional smoking kilns $\left(5.656 \times 10^{6}, 2.100 \times 10^{4}, 4.53 \times 10^{4}\right.$ and 6.67 $\times 10^{2} \mathrm{cfu} / \mathrm{g}$ ). Smoking of fish product minimizes the number of Salmonella, Total Coliforms, and E. coli found in the C. gariepinus fish as highest figures were found in fresh samples $3.575 \times 10^{4}, 1.80 \times 10^{5}$, and $4.00 \times 10^{4} \mathrm{cfu} / \mathrm{g}$, respectively and that higher temperatures during smoking resulted in more microorganisms being killed and not able to multiply [22].

Microbiological study shows the microbiological changes of hot smoked rainbow trout fillets treated with/without nisin and lysozyme during 42 days of storage at $4{ }^{\circ} \mathrm{C}$. The Total Mesophilic Aerobic Bacteria in raw rainbow trout was determined as $4.40 \log \mathrm{cfu} / \mathrm{g}$, indicating a good quality of fish. The smoking and brining process significantly reduced the microbial load of rainbow trout [16].

Aerobic Mesophilic Bacteria and Lactic Acid Bacteria were found dominant flora in both types of processed fish, with AMB reaching concentrations up to 9.5 and $7.8 \log 10$ $(\mathrm{CFU} / \mathrm{g})$ in the smoked fish and smoked dried-fish samples, respectively and Enterobacteriaceae, E. coli, B. cereus, $C$. perfringens, yeasts, and molds have been found in many samples, while other bacteria like Salmonella spp., $L$. monocytogenes, and $S$. aureus were not detected [6]. The variation showed between the minimum and maximum values indicates that it has important variability within the samples. This variation can be explained by the fact that the samples were collected from various processors and sellers where the quality of the raw material varied, as well as handling and hygiene practices. The density AMB, Enterobacteriaceae, and E. coli was also significantly higher $(p<0.05)$ in SF than in SDF [6]. This may occur due to that of smoke $d$ fish have more moisture content than that of smoked dried-fish. The high load of Aerobic Mesophilic Bacteria is likely due to a high contamination level of the raw material, and these microorganisms were not fully eliminated during the smoking treatment. The postprocess handling and storage conditions are also potential sources of renewed pollution of the processed fish [23]. The detection of E. coli in ten samples suggested a contamination by fecal matter from animal or human origin during post smoking handling. The presence of $\mathrm{B}$. cereus and $\mathrm{C}$. perfringens beyond the permitted limits may arise a hazard to consumer's health. [6]. Fish and fish products are exposed more for the spoilage as 
of bacteria biomass get increased. Smoking with woodsmoke has antibacterial activities that could effectively suppress bacterial growth. According to [9], the bacterial count significantly decreases as of increasing time of smoking at 20, 25, and 30 minutes.

\section{Conclusion}

In conclusion, Smoking fish do have so many advantages in terms of quality and safety of the products. However, there may present some harmful microbes due to improper processing and handling techniques. Making some improvements to minimize pathogenic as well as spoilage microbes and maximizing the quality of these smoked fish products is important in addition to proper processing and handling. Application of Hazard Analysis Critical Control Point plays a Lion share in here.

\section{References}

[1] Abolagba, O. J. and Melle, O. O (2008). Chemical Composition and Keeping Qualities of a Scaly Fish Tilapia (Oreochromis niloticus) Smoked with two Energy Sources. African Journal of General Agriculture. KLOBEX, 4 (2): 113117.

[2] Adelaja, O. A., Olaoye, O. J., Ikenweiwe, N. B. and AshleyDejo, S. S., 2013. Comparison of microbial load associated with smoked fish (Chrysichthys nigrodigitatus) from Oyan Lake and Ogun Waterside in Ogun State, Nigeria. Global Journal of Science Frontier Research Agriculture and Veterinary, 13 (8), pp. 200-213.

[3] Adeyeye, S. A. O., 2019. Smoking of fish: a critical review. Journal of Culinary Science \& Technology, 17 (6), pp. 559-575.

[4] Adeyeye, S. A. O., Oyewole, O. B., Obadina, A. O. and Omemu, A. M., 2015. Microbiological assessment of traditional smoked silver catfish (Chrysichthys nigrodigitatus). African Journal of Microbiology Research, 9 (2), pp. 111-116.

[5] Alasalvar, C., Miyashita, K., Shahidi, F. and Wanasundara, U. eds., 2011. Handbook of seafood quality, safety and health applications. John Wiley \& Sons.

[6] Anihouvi, D. G. H., Kpoclou, Y. E., Abdel Massih, M., Iko Afé, O. H., Assogba, M. F., Covo, M., Scippo, M. L., Hounhouigan, D. J., Anihouvi, V. and Mahillon, J., 2019. Microbiological characteristics of smoked and smoked-dried fish processed in Benin. Food science \& nutrition, 7 (5), pp. 1821-1827.

[7] Anihouvi, V. B., Kindossi, J. M. and Hounhouigan, J. D., 2012. Processing and quality characteristics of some major fermented fish products from Africa: a critical review. International Research Journal of Biological Sciences, 1 (7), pp. $72-84$.

[8] Arvanitoyannis, I. S. and Kotsanopoulos, K. V., 2012. Smoking of fish and seafood: history, methods and effects on physical, nutritional and microbiological properties. Food and bioprocess technology, 5 (3), pp. 831-853.

[9] Baten, M., Won, N. E., Sohn, J. H., Kim, J. S., Mohibbullah, M. and Choi, J. S., 2020. Improvement of Sensorial,
Physicochemical, Microbiological, Nutritional and Fatty Acid Attributes and Shelf-Life Extension of Hot Smoked HalfDried Pacific Saury (Cololabis saira). Foods, 9 (8), p. 1009.

[10] Bienkiewicz, G., Tokarczyk, G., Czerniejewska-Surma, B. and Suryn, J., 2019. Changes in the EPA and DHA content and lipids quality parameters of rainbow trout (Oncorhynchus mykiss, Walbaum) and carp (Cyprinus carpio, L.) at individual stages of hot smoking. Heliyon, 5 (12), p. e02964.

[11] Bouriga, N., Ben Ismail, H., Gammoudi, M., Faure, E. and Trabelsi, A., 2012. Effect of smoking-method on biochemical and microbiological quality of Nile tilapia (Oreochromis niloticus). American Journal of Food Technology, 7 (11), pp. 679-689.

[12] Chakroborty, T. and Chakraborty, C. S., 2017. Comparative Analysis of nutritional composition and microbial quality of salt-smoke-dried mirror carp (Cyprinus carpio var. Specularis) during storage at $22-28^{\circ} \mathrm{C}$ and $4{ }^{\circ} \mathrm{C}$. International Journal of Food Science and Nutrition, 1, pp. 86-89.

[13] Dehghani, S., Hosseini, S. V. and Regenstein, J. M., 2018. Edible films and coatings in seafood preservation: A review. Food chemistry, 240, pp. 505-513.

[14] Dike-Ndudim, J. N., Egbuobi, R. C., Onyeneke, E. N., Uduji, H. I., Nwagbaraocha, M. A., Ogamaka, I. A., Okorie, H. M., Egbuobi, L. N. and Opara, A. U., 2014. Microbial status of smoked fish, scombia scombia sold in Owerri, Imo state, Nigeria. African Journal of Clinical and Experimental Microbiology, 15 (1), pp. 35-39.

[15] FAO, I., 2016. The state of world fisheries and aquaculture 2016. Contributing to food security and nutrition for all, p. 200.

[16] Fıçıcılar, B. B. and Gençcelep, H., 2021. Influence of Nisin and Lysozyme on the Shelf Life of Hot-smoked Rainbow Trout Fillets (Oncorhynchus mykiss) during Storage at $4 \mathrm{C}$. Philippine Journal of Science, 150 (3), pp. 895-906.

[17] Fuentes, A., Fernández-Segovia, I., Barat, J. M. and Serra, J. A., 2010. Physicochemical characterization of some smoked and marinated fish products. Journal of Food Processing and Preservation, 34 (1), pp. 83-103.

[18] Hicks, D. T., 2016. Seafood safety and quality: The consumer's role. Foods, 5 (4), p. 71.

[19] Huang, X. H., Qi, L. B., Fu, B. S., Chen, Z. H., Zhang, Y. Y., Du, M., Dong, X. P., Zhu, B. W. and Qin, L., 2019. Flavor formation in different production steps during the processing of cold-smoked Spanish mackerel. Food chemistry, 286, pp. 241-249.

[20] Ibrahim, B. U., Baba, J. and Sheshi, M. S., 2014. Isolation and identification of bacteria associated with fresh and smoked fish (Clarias gariepinus) in Minna Metropolis, Niger State. Nigeria. Journal of applied and environmental microbiology, 2 (3), pp. 81-85.

[21] Kobayashi, M., Msangi, S., Batka, M., Vannuccini, S., Dey, M. M. and Anderson, J. L., 2015. Fish to 2030: the role and opportunity for aquaculture. Aquaculture economics \& management, 19 (3), pp. 282-300.

[22] Likongwe, M. C., Kasapila, W., Katundu, M. and Mpeketula, P., 2019. Microbiological quality of traditional and improved kiln smoked catfish (Clarias gariepinus; Pisces; Clariidae) in Lake Chilwa Basin. Food science \& nutrition, 7 (1), pp. 281286. 
[23] Marc, K., Philippe, S., Eustache, H., Boniface, Y., Dominique, S. and Souaïbou, F., 2014. Microbiological quality of smoked mackerel (Trachurus trachurus), sold in Abomey-Calavi township markets, Benin. cancer, 8, p. 9.
[24] Mei, J., Ma, X. and Xie, J., 2019. Review on natural preservatives for extending fish shelf life. Foods, 8 (10), p. 490. 